\title{
Profil Plumbum (Pb) dan Cadmium (Cd) sebagai Kontaminan Dampak Penggunaan Agrokimia serta Remediasi Biji Kedelai Menggunakan Swelling Agent pada Khelasi dengan Asam Sitrat
}

\author{
Sapto Priyadi ${ }^{1 *}$, Purnama Darmaji $^{2)}$, Umar Santoso $^{2)}$, dan Pudji Hastuti²) \\ ${ }^{1)}$ Program Studi Agroteknologi, Fakultas Pertanian, Universitas Tunas Pembangunan, Surakarta 57139 \\ ${ }^{2)}$ Program Studi Ilmu Pangan, Fakultas Teknologi Pertanian, Universitas Gadjah Mada, Yogyakarta 55281
}

Diterima 13-11-2012Ｄisetujui 04-09-2013

\begin{abstract}
This research were aimed to know the plumbum $(\mathrm{Pb})$ and cadmium $(\mathrm{Cd})$ profile on soybean seeds as contaminants of the impact use of agrochemistry material impact and to know of swelling agent of N,N-dimethylformamide (DMF) needs at certain level of $\mathrm{pH}$ in chelation with citric acid. The results showed that the content of $\mathrm{Pb}$ in soybean seeds at cultivation system agrochemistry materials i.e. $0.63 \mathrm{ppm}$, while cultivation system without agrochemistry materials i.e. $0.46 \mathrm{ppm}$. Cd content in soybean seeds at cultivation system agrochemistry materials i.e. $0.05 \mathrm{ppm}$ and the cultivation system without agrochemistry materials i.e. $0.1 \mathrm{ppm}$. Acceptable daily intake in terms of $\mathrm{Pb}$ content in soybean after treatment increases to 2.93 times compared before treatment (11.3379 to $33.2099 \mathrm{~g}$ per body weight per day). Acceptable daily intake in terms of the content of the $\mathrm{Cd}$ in soybean after treatment increases to 5.26 times compared before treatment. The value of the bioconcentration factor which expressed an accumulation of $\mathrm{Pb}$ in soybean seeds on both cultivation is low system $(\mathrm{BCF}<250)$, while for $\mathrm{Cd}$ is a moderate to high level $(1.000<\mathrm{BCF}>250)$. Cd reduction on soybeans seeds for all chelation treatment was maximum (not detected-detection limits was $0.01 \mathrm{ppm}$ ), while the highest reduction of $\mathrm{Pb}$ occurs at swelling agent $\mathrm{N}, \mathrm{N}$ dimethylformamide $15 \mathrm{~mL}$ at $\mathrm{pH} 10$.
\end{abstract}

Keywords: cadmium, chelation, heavy metal, plumbum, swelling-agent

\begin{abstract}
ABSTRAK
Penelitian ini bertujuan untuk mengetahui profil $\mathrm{Pb}$ dan $\mathrm{Cd}$ pada biji kedelai sebagai kontaminan dampak penggunaan agrokimia serta untuk mengetahui kebutuhan agen pengembang N,N-dimetilformamida (DMF) pada pH tertentu dalam kelasi dengan asam sitrat. Hasil penelitian menunjukkan bahwa kandungan $\mathrm{Pb}$ dalam biji kedelai pada sistem budidaya menggunakan bahan agrokimia adalah $0,63 \mathrm{ppm}$, sedangkan pada sistem budidaya tanpa bahan agrokimia adalah $0,46 \mathrm{ppm}$. Kandungan Cd dalam biji kedelai pada sistem budidaya menggunakan bahan agrokimia adalah 0,05 ppm dan pada sistem budidaya tanpa bahan agrokimia adalah $0,1 \mathrm{ppm}$. Acceptable daily intake ditinjau dari kandungan $\mathrm{Pb}$ pada kedelai setelah perlakuan meningkat menjadi 2,93 kali dibandingkan sebelum perlakuan (11,3379 menjadi 33,2099 g per berat badan per hari). Acceptable daily intake ditinjau dari kandungan Cd pada kedelai setelah perlakuan meningkat menjadi 5,26 kali dibandingkan sebelum perlakuan. Nilai bio-concentration factor yang menyatakan akumulasi $\mathrm{Pb}$ dalam biji kedelai pada kedua sistem budidaya adalah rendah $(\mathrm{BCF}<250)$, sedangkan untuk $\mathrm{Cd}$ adalah sedang sampai tinggi $(1,000<\mathrm{BCF}>250)$. Reduksi $\mathrm{Cd}$ pada biji kedelai untuk semua perlakuan kelasi mencapai maksimum (tidak terdeteksi-batas deteksi 0,01 ppm), sedangkan reduksi $\mathrm{Pb}$ tertinggi terjadi pada perlakuan agen pengembang N,N-dimetilformamida $15 \mathrm{~mL}$ pada kondisi $\mathrm{pH}$ kelasi 10.
\end{abstract}

Kata Kunci: agen pengembang, kadmium, logam berat, kelasi, plumbum

\section{PENDAHULUAN}

Pencemaran logam berat pada lahan pertanian merupakan masalah lingkungan, yang dapat mengurangi

*Telp: +628121537245

Email: saptopriyadi@ymail.com produktivitas tanaman dan keamanan produk sebagai pangan dan pakan (Zheljazkov et al. 2006). Sumber pencemaran dapat berupa residu bahan agrokimia seperti pupuk dan pestisida yang dalam penggunaannya cenderung 
berlebihan serta limbah industri yang menggunakan bahan kimia tertentu dan pengolahan limbahnya kurang baik. $\mathrm{Cd}$ tersebar dalam lingkungan alam, berasal dari kegiatan manusia maupun proses mineralisasi batuan alam (Drazic \& Mihailovic 2005).

Kandungan Cd dalam tanah pertanian disebabkan oleh aplikasi pupuk fosfat (Drazic \& Mihailovic 2005). Apabila pupuk tersebut digunakan secara terus menerus dengan dosis dan intensitas tinggi dapat meningkatkan $\mathrm{Pb}$ dan $\mathrm{Cd}$ yang tersedia dalam tanah, sehingga meningkatkan serapan $\mathrm{Pb}$ dan Cd oleh tanaman (Charlena 2004). Pb dan Cd diangkut melalui pembuluh xylem dan didistribusikan pembuluh floem hingga mencapai biji dalam bentuk X-S-Cd (Mendoza-Cózatl et al. 2011).

Tanaman mudah menyerap Cd dari tanah dan mengangkutnya ke tunas, sehingga dikonsumsi oleh manusia melalui rantai makanan dan mengancam kesehatan (Drazic \& Mihailovic 2005). Kadmium dan timbal yang terakumulasi dalam sistem biologis bersifat sangat beracun (Ansari et al. 2009). Kadar $\mathrm{Pb}$ dan Cd yang tinggi berimplikasi terhadap kesehatan. Plumbum menyebabkan anemia dan defisiensi hemoglobin, disfungsi ginjal dan kerusakan otak (neuropathy). Kadmium dapat memotivasi demineralisasi tulang, meningkatkan kerapuhan tulang dan risiko fraktur, menyebabkan timbulnya anemia dan hipertensi. Pada testis menyebabkan hyperplasia yang merupakan permulaan terjadinya kanker. Masuknya $\mathrm{Pb}$ dan $\mathrm{Cd}$ ke dalam makhluk hidup dapat melalui pangan dan air minum, inhalasi udara dan penetrasi melalui kulit (Balia et al. 2007).

Tanaman kedelai memiliki kapasitas yang besar untuk menyerap $\mathrm{Cd}$ tanah. Cd dalam jaringan tumbuhan berada dalam urutan akar > batang > daun. Keadaan tersebut menunjukkan arah perjalanan $\mathrm{Cd}$ dalam sistem tanah tanaman. Lebih lanjut dijelaskan bahwa penambahan $\mathrm{Cd}$ ke dalam media tanam $\left(5 \mathrm{mgkg}^{-1}\right)$ menyebabkan akumulasi Cd pada jaringan tanaman kedelai meningkat, yang secara berturut-turut meningkatkan kandungan $\mathrm{Cd}$ dalam akar $(120,63 \pm 7,19)$, batang $(88,40 \pm 4,33)$, dan daun $(45,35 \pm 2,61) \mathrm{mgkg}^{-1}$ (Yong et al. 2008). Hasil penelitian serupa tentang kandungan $\mathrm{Cd}$ dalam jaringan tanaman kedelai biji (kotiledon), yaitu sebelum dan sesudah penambahan $\mathrm{Cd}$ $\left(3 \mathrm{mgkg}^{-1}\right) \mathrm{ke}$ dalam media tanam, masing-masing $48 \pm$ $5,2 \mathrm{mgkg}^{-1}$ dan $61 \pm 7,2 \mathrm{mgkg}^{-1}$ (Drazic \& Mihailovic 2005).

Asam organik yang memiliki gugus fungsional $-\mathrm{COOH}$, $-\mathrm{OH}$ fenolat maupun $-\mathrm{OH}$ alkoholat, mempunyai peluang untuk membentuk komplek dengan ion logam (Ariyanto
2006). Meningkatnya $\mathrm{pH}$ akan menyebabkan ikatan hidrogen semakin lemah sehingga agregat akan terpisah satu sama lain. Keadaan tersebut dipengaruhi oleh disosiasi gugus fungsional yang bersifat asam pada asam humat seperti -COOH. Umumnya gugus - $\mathrm{COOH}$ terdisosiasi pada $\mathrm{pH}$ sekitar 4-5, sedangkan gugus $-\mathrm{OH}$ fenolat atau $-\mathrm{OH}$ alkoholat terdisosiasi pada $\mathrm{pH}$ sekitar 8-10. Berdasarkan hal tersebut dapat dinyatakan bahwa $\mathrm{pH}$ yang relatif tinggi akan meningkatkan konsentrasi - $\mathrm{COO}^{-}$yang dapat berfungsi sebagai ligan (Herjuna 2011).

Jumlah proton yang terlepas juga ditentukan oleh $\mathrm{pH}$ lingkungan. Pengaruh $\mathrm{pH}$ terhadap pelepasan proton dapat dikaitkan dengan nilai pKa-nya. Nilai pKa adalah $\mathrm{pH}$ sistem larutan pada saat konsentrasi asam sama dengan konsentrasi konjugatnya (sisa asam). Nilai pKa asam sitrat masing-masing 3,13 $\left(\mathrm{pKa}_{1}\right) ; 4,76\left(\mathrm{pKa}_{2}\right)$; dan 6,4 (pKa $)_{3}$. Apabila pH lingkungan di atas nilai pKa-nya, maka proton dalam asam akan terlepas semua. Sebaliknya apabila $\mathrm{pH}$ di bawah $\mathrm{pKa}-$ nya maka senyawa organik tersebut ada dalam bentuk asam dan tidak bermuatan. Pada $\mathrm{pH}$ kurang dari 3, semua asam organik tertekan, sehingga asam tidak bermuatan. Pada $\mathrm{pH}$ antara 3 dan 9 merupakan daerah disosiasi gugus karboksil, dan pada $\mathrm{pH}$ lebih besar dari 9 merupakan daerah disosiasi gugus $\mathrm{OH}$ fenolat (Ismail \& Hanudin 2005). Umumnya gugus - $\mathrm{COOH}$ terdisosiasi pada $\mathrm{pH}$ sekitar 4-5, sedangkan gugus -OH fenolat atau -OH alkoholat terdisosiasi pada $\mathrm{pH}$ sekitar 8-10 (Ariyanto 2006).

Pada penelitian ini, N,N-dimetilformamida (DMF) berfungsi sebagai agen pengembang dan juga media reaksi. Menurut Li, et al. (2010), esterifikasi cepat pada adsorpsi logam berat menggunakan agen pengembang $\mathrm{N}, \mathrm{N}$ dimetilformamida (DMF) pada spent grain dioptimasi menggunakan pengkelat asam sitrat sebanyak $1 \mathrm{~g}$ untuk $5 \mathrm{~g}$ biji.

Tujuan dari penelitian ini adalah untuk mengetahui profil $\mathrm{Pb}$ dan $\mathrm{Cd}$ pada biji kedelai hasil sistem budidaya menggunakan agrokimia dan non agrokimia, serta untuk mengetahui remediasi biji kedelai menggunakan agen pengembang pada derajat keasaman $(\mathrm{pH})$ tertentu dalam khelasi menggunakan asam sitrat.

\section{BAHAN DAN METODE}

Bahan yang digunakan dalam penelitian ini terdiri dari bahan utama dan bahan kimia untuk analisis. Bahan utama berupa biji kedelai yang dalam teknik budidayanya menggunakan bahan agrokimia, agen pengembang $\mathrm{N}, \mathrm{N}-$ 
dimetilformamida (DMF), katalis sodium hypophosphite monohydrate, pengkelat asam sitrat, $\mathrm{H}_{2} \mathrm{SO}_{4}, \mathrm{HCl}, \mathrm{NaOH}$, $\mathrm{HNO}_{3}, \mathrm{HClO}_{4}$, dan larutan standar. Alat yang digunakan dalam penelitian ini adalah: magnetic stirrer, erlenmeyer, $\mathrm{pH}$ meter, oven, penangas, dan Atomic Absorption Spectrophotometer-flame (AAS Jena ContrAA 300).

Remediasi biji kedelai yang terkontaminasi logam berat meliputi faktor volume DMF, terdiri dari 3 variasi yaitu: 15 , 25 dan $35 \mathrm{~mL}$ yang dikombinasikan dengan faktor derajat keasaman $(\mathrm{pH})$ 5; 7,5 dan 10. Berdasarkan analisis varian apabila diketahui adanya perlakuan yang berbeda nyata, maka untuk mengetahui perlakuan mana yang terbaik dalam mereduksi $\mathrm{Pb}$ dan $\mathrm{Cd}$, dilanjutkan dengan analisis Duncan's Multiple Range Test (DMRT).

Pelaksanaan penelitian remediasi biji kedelai dilakukan melalui kelasi $\mathrm{Pb}$ dan $\mathrm{Cd}$ dengan menggunakan asam sitrat yang dilarutkan dalam DMF $15 \mathrm{~mL}$ pada $\mathrm{pH} 10$, selama waktu kontak tertentu dengan katalis $\mathrm{NaH}_{2} \mathrm{PO}_{4}-\mathrm{H}_{2} \mathrm{O}(1 \mathrm{~g})$, menurut metode Li et al. 2010. Setelah reaksi berlangsung, dilakukan pemisahan padatan dan pelarut, residu asam sitrat dicuci dengan etanol 96\% dan air deionisasi, residu DMF pada padatan dikeringkan pada $60^{\circ} \mathrm{C}$ selama 12 jam (Li et al. 2010). Akhirnya padatan siap dianalisis kandungan $\mathrm{Pb}$ dan $\mathrm{Cd}$ menggunakan AAS yang sebelumnya dilakukan preparasi sampel (destruksi basah).

Persiapan pengujian. sebelum dilakukan pengujian residu $\mathrm{Pb}$ dan $\mathrm{Cd}$, sampel uji dilakukan destruksi basah dan hindari pemanasan yang membuat sampel mengering. Preparasi dan pengukuran konsentrasi masing-masing larutan kerja yang telah dipersiapkan dengan panjang gelombang untuk $\mathrm{Pb}=217 \mathrm{~nm}$ dan $\mathrm{Cd}=228 \mathrm{~nm}$. Perhitungan konsentrasi $\mathrm{Pb}$ atau $\mathrm{Cd}$, dengan rumus:

$$
\mathrm{C}=\mathrm{Ax}(25 \mathrm{~mL} / \mathrm{B})
$$

$\mathrm{A}=$ konsentrasi yang didapat dari hasil pengukuran,

$\mathrm{B}=$ berat sampel dalam gram dan

$\mathrm{C}=$ konsentrasi $\mathrm{Pb}$ atau $\mathrm{Cd}$

(Association of Analytical Chemist 2005; Gonzales \& Herrador 2007).

\section{HASIL DAN PEMBAHASAN}

Profil $\mathrm{Pb}$ dan $\mathrm{Cd}$ pada kedelai dalam sistem budidaya menggunakan bahan agrokimia dan tanpa agrokimia, ditampilkan pada Gambar 1 dan Gambar 2. Berdasarkan hasil penelitian dapat dinyatakan bahwa kandungan $\mathrm{Pb}$ dan $\mathrm{Cd}$ pada biji kedelai hasil budidaya dengan bahan agrokimia sudah berada di atas ambang batas residu yang ditetapkan
WHO, yaitu masing-masing 12,6 kali dan 10 kali lipat dari ambang batas residu. Hal tersebut disebabkan oleh sistem budidaya kedelai yang menggunakan bahan agrokimia, berupa pupuk anorganik NPK ponska (15:15:15) dengan dosis $75 \mathrm{kgha}^{-1}$ dan SP 36 dengan dosis $50 \mathrm{kgha}^{-1}$. Menurut Drazic dan Mihailovic (2005), keberadaan Cd dalam tanah pertanian pada umumnya disebabkan oleh penggunaan agrokimia yaitu pupuk fosfat. Kisaran konsentrasi $\mathrm{Cd}$ pada pupuk fosfat $0,1-170 \mathrm{ppm}$ dan pada pupuk nitrat 0,05-8,5 ppm. Kisaran konsentrasi $\mathrm{Pb}$ pada pupuk fosfat 7-225 ppm, sedangkan pada pupuk nitrat 2-27 ppm.

Kandungan $\mathrm{Pb}$ dan $\mathrm{Cd}$ pada biji kedelai hasil budidaya tanpa agrokimia juga sudah berada di atas ambang batas residu yang ditetapkan WHO, yaitu masing-masing 9,2 dan 20 kali lipat dari ambang batas residu. Perihal tersebut disebabkan oleh sejarah penggunaan lahan pada musim tanam sebelumnya yang telah ditanami padi dengan sistem budidayanya menggunakan bahan agrokimia (urea $300 \mathrm{kgha}^{-1}$, NPK ponska $200 \mathrm{kgha}^{-1}$ dan SP 36 dengan dosis $150 \mathrm{kgha}^{-1}$ ). Hal ini memberikan andil pada peningkatan residu $\mathrm{Pb}$ dalam tanah yang berpeluang diserap oleh akar tanaman kedelai pada musim tanam berikutnya. Menurut Charlena
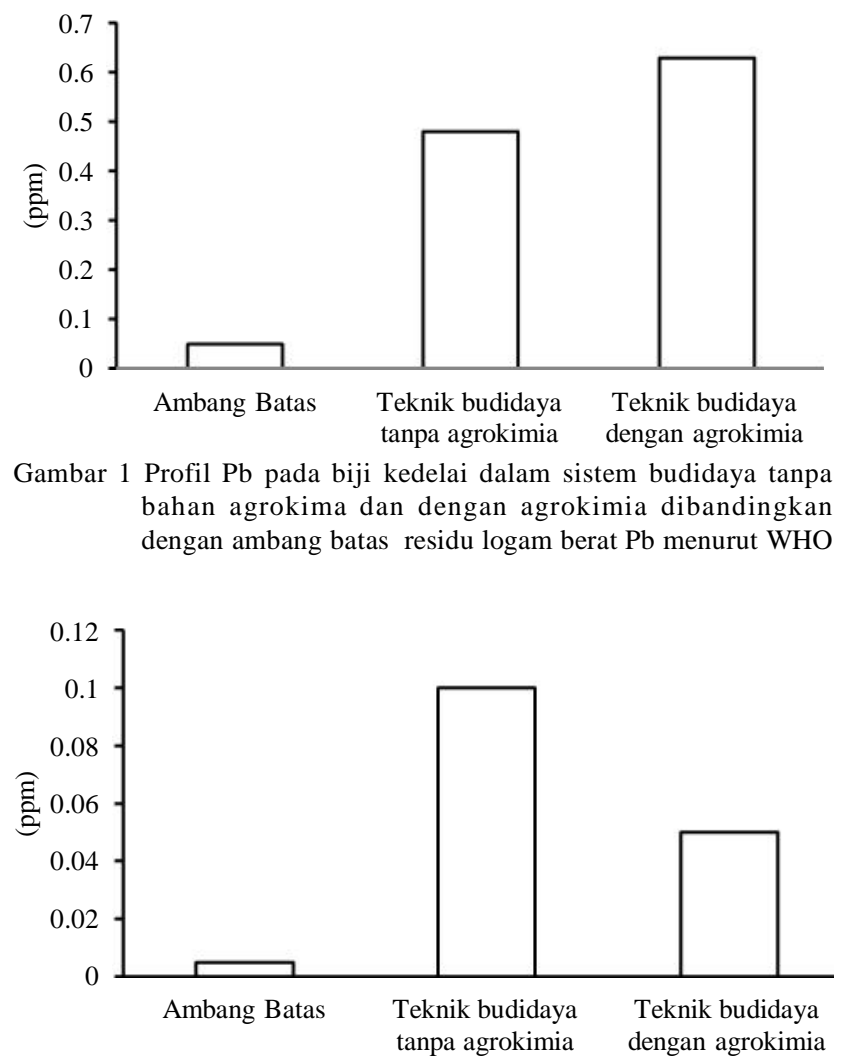

Gambar 2 Profil Cd pada biji kedelai dalam sistem budidaya tanpa bahan agrokima dan dengan agrokimia dibandingkan dengan ambang batas residu logam berat $\mathrm{Cd}$ menurut WHO 
(2004), apabila pupuk anorganik tersebut digunakan secara terus menerus dengan dosis dan intensitas yang tinggi dapat meningkatkan $\mathrm{Pb}$ yang tersedia dalam tanah, sehingga meningkatkan serapan $\mathrm{Pb}$ oleh tanaman.

Hasil penelitian tentang residu $\mathrm{Pb}$ sebagaimana dilihat pada Gambar 3, dapat dinyatakan bahwa kedelai yang direkomendasikan berdasarkan acceptable daily intake setelah perlakuan agen pengembang pada kelasi menggunakan asam sitrat (pasca remediasi) meningkat menjadi 2,93 kali dibandingkan sebelum perlakuan (sebelum remediasi), yaitu dari 11,3379 g menjadi 33,2099 g per kg berat badan per hari. Kondisi tersebut dicapai pada perlakuan $\mathrm{A}_{1} \mathrm{~B}_{3}$ (remediasi biji kedelai menggunakan agen pengembang $15 \mathrm{~mL}$ pada $\mathrm{pH} 10$ dalam kelasi menggunakan asam sitrat). Berdasarkan uji (DMRT 5\%), dinyatakan bahwa perlakuan $\mathrm{A}_{1} \mathrm{~B}_{3}$ berbeda tidak nyata dengan perlakuan $\mathrm{A}_{3} \mathrm{~B}_{3}$ (remediasi biji kedelai menggunakan agen pengembang $35 \mathrm{~mL}$ pada $\mathrm{pH}$ 10).
Hasil penelitian tentang residu $\mathrm{Cd}$ sebagaimana disajikan pada Gambar 4, dapat dinyatakan bahwa kedelai yang direkomendasikan berdasarkan acceptable daily intake setelah perlakuan agen pengembang pada kelasi menggunakan asam sitrat (pasca remediasi) untuk semua perlakuan meningkat menjadi 5,26 kali dibandingkan sebelum perlakuan (sebelum remediasi), yaitu dari $214,29 \mathrm{~g}$ menjadi $1.127,82 \mathrm{~g}$ per $\mathrm{kg}$ berat badan per hari. Hal tersebut disebabkan oleh remediasi biji kedelai ditinjau dari residu $\mathrm{Cd}$, berdasarkan analisis AAS tidak terdeteksi untuk semua perlakuan (batas deteksi 0,01 ppm), yang berarti recovery remediasi biji kedelai menggunakan asam sitrat ditentukan oleh agen pengembang dan derajat $\mathrm{pH}$.

Penggunaan agen pengembang (DMF-dimetilformamida) yang bersifat polar (hidrofilik) aprotik solven, akan memfasilitasi reaksi yang mengikuti mekanisme polar. agen pengembang yang tepat bisa memutus hubungan di antara bahan lignoselulosis dan memecah ikatan-ikatan intra

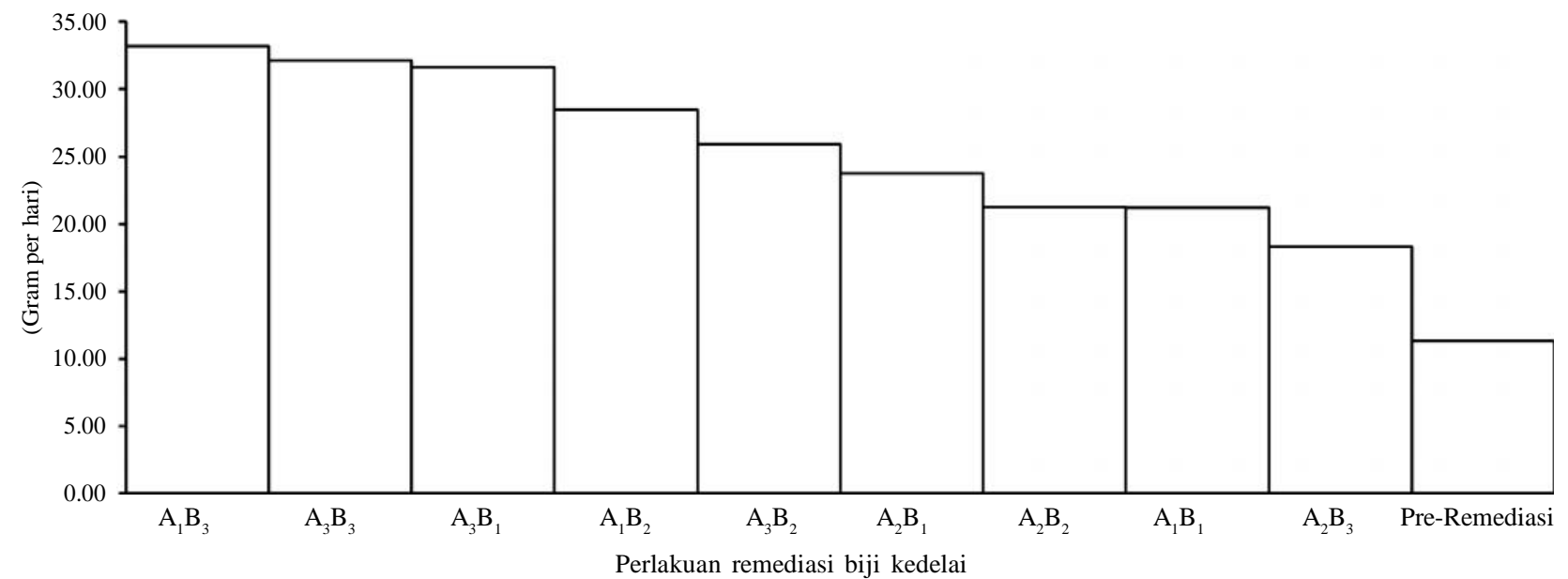

Gambar 3 Profil Pb pada kedelai yang direkomendasikan berdasarkan acceptable daily intake

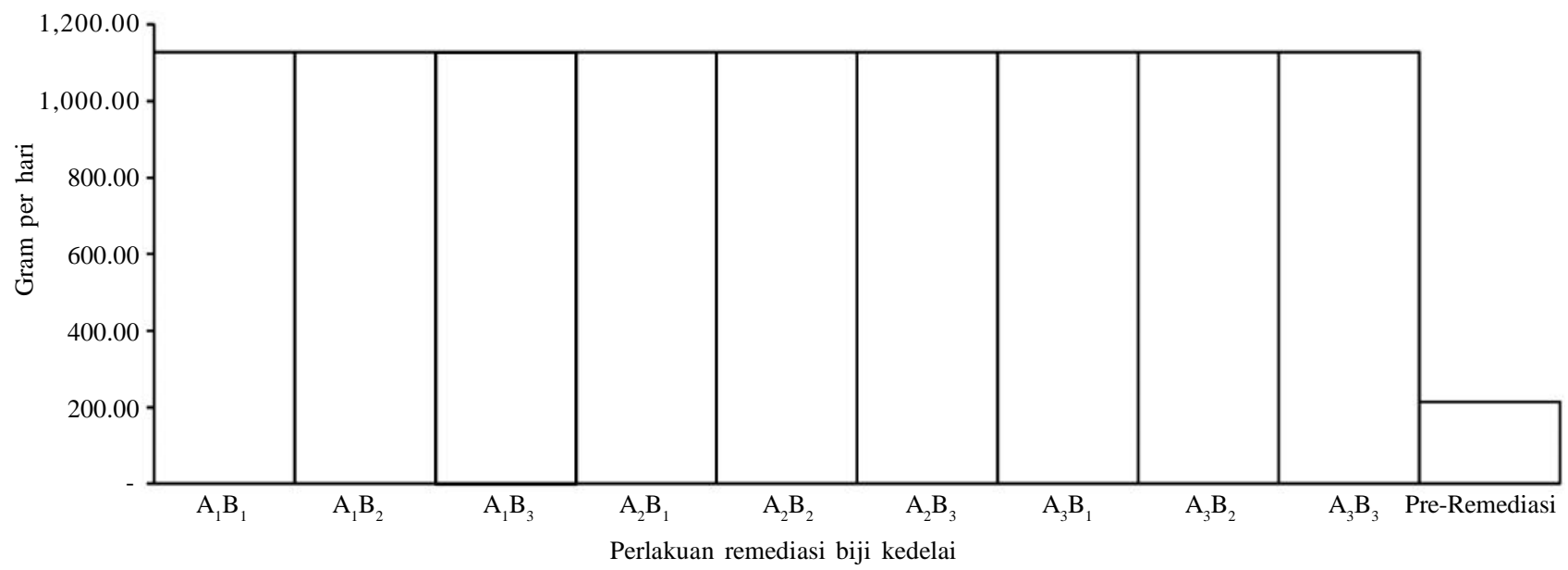

Gambar 4 Profil Cd pada kedelai yang direkomendasikan berdasarkan acceptable daily intake 
dan inter-molekuler untuk meningkatkan aktivitas reaksinya (Li et al. 2010).

Meningkatnya $\mathrm{pH}$ larutan akan membuat gugus fungsional asam organik menjadi aktif dan nilai konstanta distribusi ion logam/radionuklida akan menurun bersamaan dengan meningkatnya $\mathrm{pH}$ larutan. Jumlah proton yang terlepas juga ditentukan oleh $\mathrm{pH}$ lingkungan. Pada $\mathrm{pH}$ kurang dari 3 semua asam organik tertekan, sehingga asam tidak bermuatan. Pada $\mathrm{pH}$ antara 3 dan 9 merupakan daerah disosiasi gugus karboksil, dan pada $\mathrm{pH}$ lebih besar dari 9 merupakan daerah disosiasi gugus $\mathrm{OH}$ fenolat (Ismail \& Hanudin 2005). Umumnya gugus - $\mathrm{COOH}$ terdisosiasi pada $\mathrm{pH}$ sekitar 4-5, sedangkan gugus $-\mathrm{OH}$ fenolat atau $-\mathrm{OH}$ alkoholat terdisosiasi pada pH sekitar 8-10 (Ariyanto 2006). Menurut Zander (2009), kemampuan recovery sangat tergantung pada $\mathrm{pH}$. Pada $\mathrm{pH}<5$, efektivitas kelasi Cd kurang dari $20 \%$, tetapi meningkat menjadi hampir $100 \%$ pada $\mathrm{pH} 7$. Peneliti lain menyatakan bahwa kelasi maksimum $\mathrm{Cd}$ berlangsung pada $\mathrm{pH} 5$, dan $\mathrm{Pb}$ pada $\mathrm{pH} 4$ (Shaha et al.
2008). Di sisi lain, kapasitas tukar kation maksimum logam berat juga tergantung pada $\mathrm{pH}$, misalnya $\mathrm{Pb}$ pada $\mathrm{pH}$ 6,0 dan Cd pada pH 4,5 (Sridhar et al. 2009).

Berdasarkan hasil penelitian sebagaimana disajikan pada Gambar 5 dan 6, dapat dinyatakan bahwa Bio-Concentration Factor (BCF) biji kedelai masing-masing 7,28 dan 4,83 artinya kemampuan akumulasi $(\mathrm{Pb})$ adalah rendah, baik pada sistem budidaya tanpa bahan agrokimia maupun pada sistem budidaya menggunakan bahan agrokimia. Pada Gambar 7 dapat dinyatakan bahwa kemampuan akumulasi Cd tinggi untuk sistem budidaya tanpa bahan agrokimia, sedangkan untuk sistem budidaya menggunakan bahan agrokimia (Gambar 8), kemampuan akumulasi Cd sedang.

Translokasi logam dari akar ke bagian tanaman lain setelah menembus endodermis akar, logam mengikuti aliran transpirasi ke bagian atas tanaman. Hasil penelitian serupa tentang kandungan $\mathrm{Cd}$ dalam jaringan tanaman kedelai biji (Kotiledon) sebelum dan sesudah penambahan Cd sebanyak

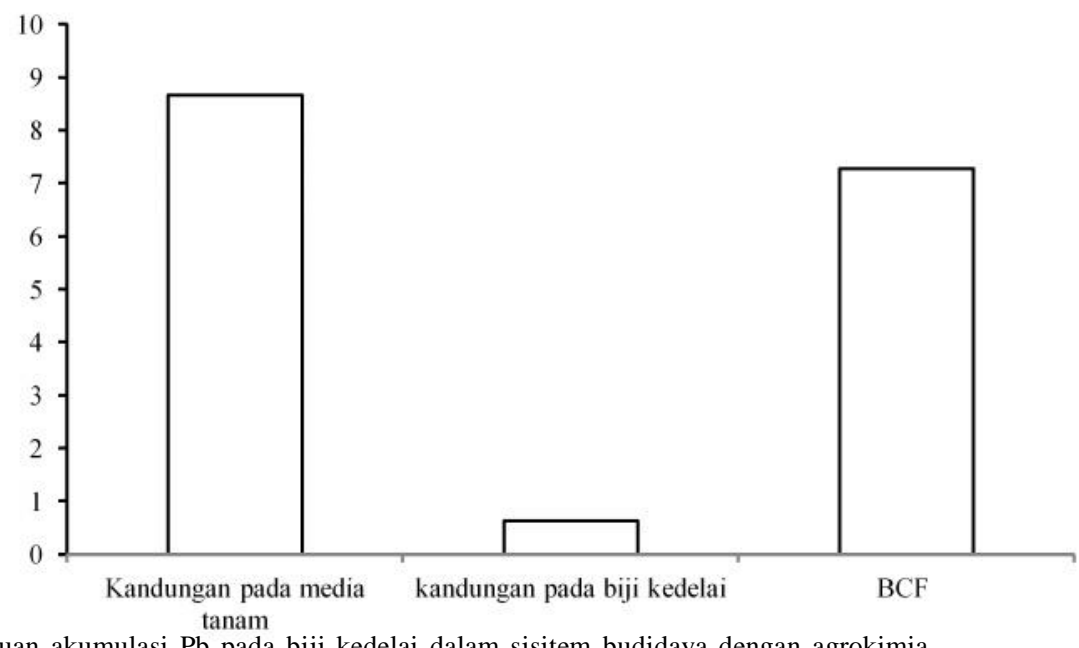

Gambar 5 Profil kemampuan akumulasi $\mathrm{Pb}$ pada biji kedelai dalam sisitem budidaya dengan agrokimia

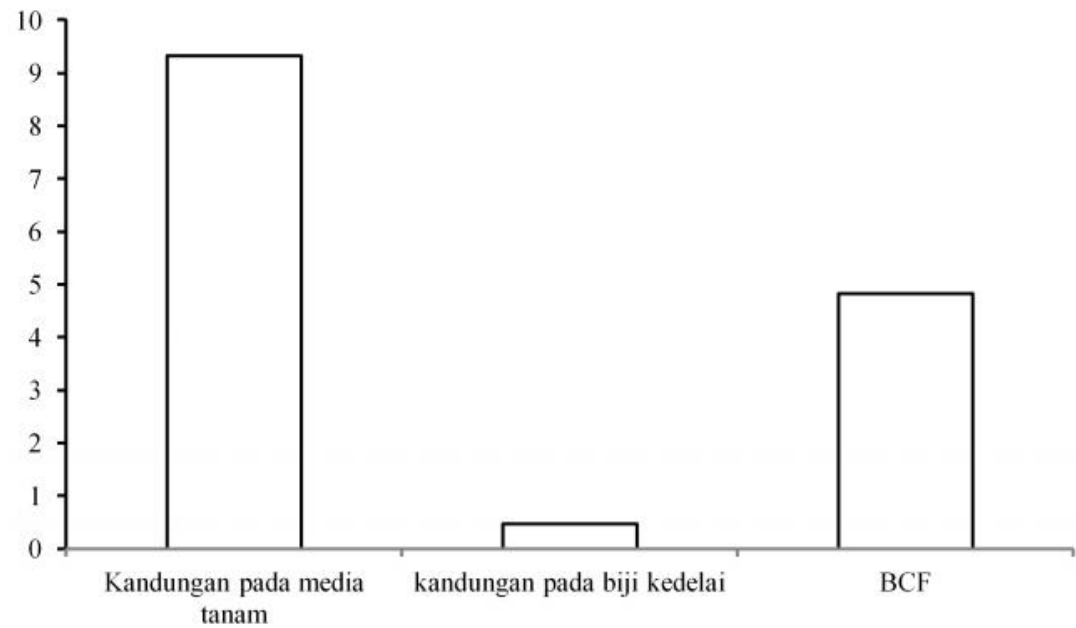

Gambar 6 Profil kemampuan akumulasi $\mathrm{Pb}$ pada biji kedelai dalam sisitem budidaya tanpa agrokimia 


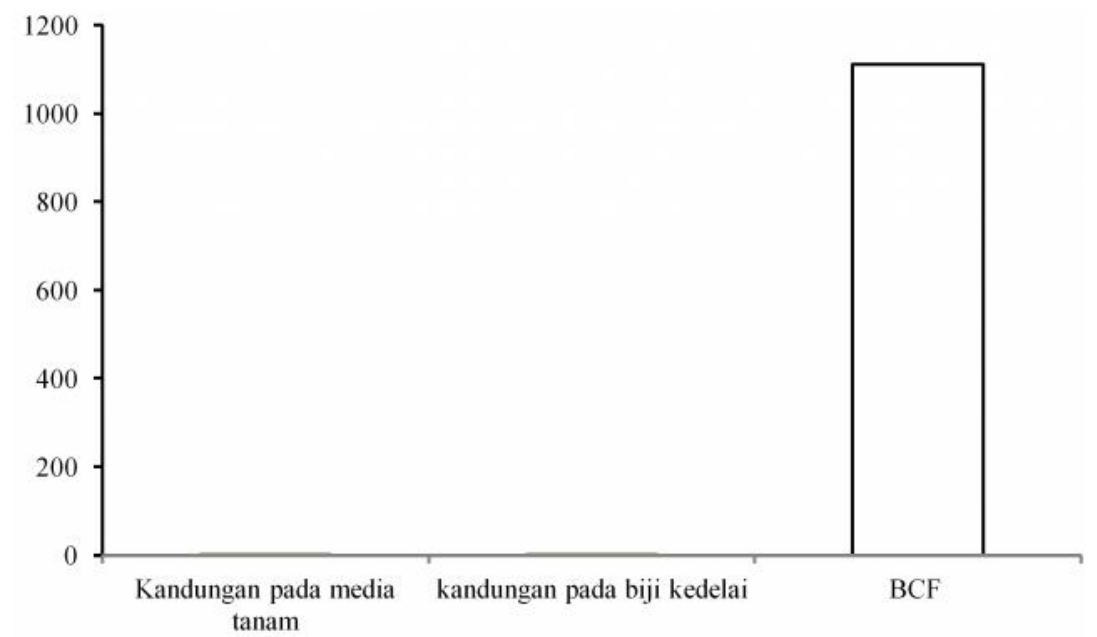

Gambar 7 Profil kemampuan akumulasi Cd pada biji kedelai dalam sisitem budidaya tanpa agrokimia

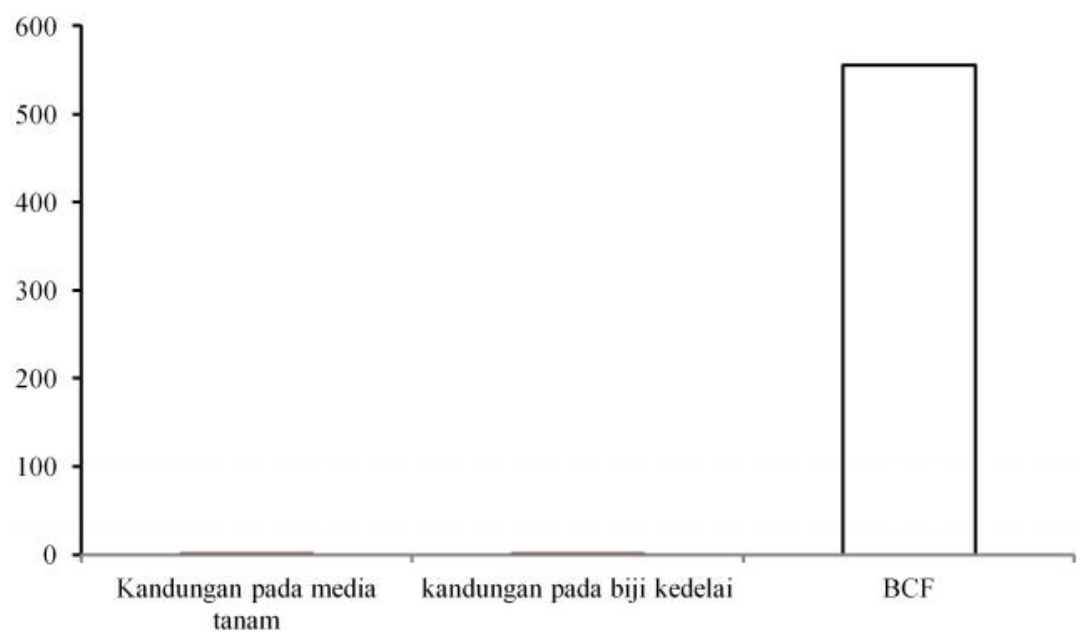

Gambar 8 Profil kemampuan akumulasi Cd pada biji kedelai dalam sisitem budidaya dengan agrokimia

$3 \mathrm{mgkg}^{-1}$ ke dalam media tanam, masing-masing $48 \pm 5,2$ $\mathrm{mgkg}^{-1}$ dan $61 \pm 7,2 \mathrm{mgkg}^{-1}$ (Drazic \& Mihailovic 2005).

Reduksi Cd pada biji kedelai untuk semua perlakuan adalah maksimum, karena tidak terdeteksi (batas deteksi Cd 0,01 ppm). Berdasarkan hasil penelitian sebagaimana disajikan pada Tabel 1, dapat dinyatakan bahwa reduksi $\mathrm{Pb}$ tertinggi dicapai oleh perlakuan $\mathrm{A}_{1} \mathrm{~B}_{3}$ (remediasi biji kedelai menggunakan agen pengembang $15 \mathrm{~mL}$ pada $\mathrm{pH} 10$ dalam kelasi menggunakan asam sitrat).

Penggunaan agen pengembang yang tepat bisa memutus hubungan di antara bahan lignoselulosis dan memecah ikatan-ikatan intra dan inter-molekuler untuk meningkatkan aktivitas reaksinya (Li et al. 2010). Asam sitrat merupakan chelating agent yang sesuai untuk dekontaminasi logam seperti $\mathrm{Pb}$ (Ullah 2007). Asam sitrat memiliki tiga gugus karboksilat $\mathrm{COOH}$ yang dapat melepas proton $\left(\mathrm{H}^{+}\right)$dalam larutan. Meningkatnya $\mathrm{pH}$ larutan akan membuat gugus fungsional asam organik menjadi aktif dan
Tabel 1 Reduksi Pb pada biji kedelai dengan agen pengembang (DMF) pada kondisi $\mathrm{pH}$ khelasi dengan pengkhelat asam sitrat

\begin{tabular}{lcc}
\hline Perlakuan & Reduksi Pb $(\%)$ & Notasi \\
\hline $\mathrm{A}_{1} \mathrm{~B}_{3}$ & 65,855 & $\mathrm{~b}$ \\
$\mathrm{~A}_{3} \mathrm{~B}_{3}$ & 64,694 & $\mathrm{~b}$ \\
$\mathrm{~A}_{3} \mathrm{~B}_{1}$ & 64,150 & $\mathrm{~b}$ \\
$\mathrm{~A}_{1} \mathrm{~B}_{2}$ & 60,175 & $\mathrm{ab}$ \\
$\mathrm{A}_{3} \mathrm{~B}_{2}$ & 56,247 & $\mathrm{ab}$ \\
$\mathrm{A}_{2} \mathrm{~B}_{1}$ & 52,261 & $\mathrm{ab}$ \\
$\mathrm{A}_{2} \mathrm{~B}_{2}$ & 46,676 & $\mathrm{ab}$ \\
$\mathrm{A}_{1} \mathrm{~B}_{1}$ & 46,558 & $\mathrm{ab}$ \\
$\mathrm{A}_{2} \mathrm{~B}_{3}$ & 38,068 & $\mathrm{a}$ \\
\hline
\end{tabular}

Keterangan: Perlakuan yang diikuti dengan notasi sama menunjukkan berbeda tidak nyata pada taraf $5 \%$

nilai konstanta distribusi ion logam akan menurun bersamaan dengan meningkatnya pH larutan. Menurut Zander (2009), kemampuan recovery sangat tergantung pada $\mathrm{pH}$. Pada $\mathrm{pH}$ $<5$, efektivitas kelasi Cd kurang dari 20\%, tetapi meningkat menjadi hampir $100 \%$ pada $\mathrm{pH} 7$. 


\section{SIMPULAN}

Kandungan $\mathrm{Pb}$ pada biji kedelai hasil budidaya tanpa dan atau dengan bahan agrokimia sudah berada di atas ambang batas residu yang ditetapkan WHO yaitu 9,212,6 kali, sedangkan Cd 10-20 di atas ambang batas residu. Acceptable daily intake ditinjau dari kandungan plumbum pada biji kedelai setelah perlakuan meningkat menjadi 2,93 kali (dari 11,3379 menjadi 33,2099 g per kg berat badan per hari). Kondisi tersebut dicapai pada perlakuan agen pengembang $15 \mathrm{~mL}$ pada $\mathrm{pH} 10$ dengan pengkelat asam sitrat. Acceptable daily intake ditinjau dari kandungan $\mathrm{Cd}$ pada biji kedelai meningkat menjadi 5,26 kali. Kondisi tersebut dicapai pada semua perlakuan.

Kemampuan akumulasi $\mathrm{Pb}$ pada biji kedelai dalam sistem budidaya tanpa dan atau dengan menggunakan bahan agrokimia termasuk dalam kriteria rendah $(\mathrm{BCF}<250)$. Kemampuan akumulasi Cd pada biji kedelai dalam sistem budidaya tanpa menggunakan bahan agrokimia termasuk dalam kriteria tinggi ( $\mathrm{BCF}>1.000)$, sedangkan pada sistem budidaya dengan menggunakan bahan agrokimia masuk dalam kriteria sedang $(1.000>\mathrm{BCF}>250)$. Reduksi Cd pada biji kedelai pada semua perlakuan maksimum, sedangkan reduksi $\mathrm{Pb}$ tertinggi dicapai oleh perlakuan agen pengembang (N,N-dimetilformamida) $15 \mathrm{~mL}$ pada $\mathrm{pH} 10$ dengan pengkelat asam sitrat.

\section{UCAPAN TERIMA KASIH}

Penulis mengucapkan terima kasih kepada Direktorat Jenderal Pendidikan Tinggi Departemen Pendidikan Nasional yang telah memberikan bantuan dana pada Penelitian Fudamental sesuai dengan kontrak Nomor: 009/006.2/PP/SP/ 2012.

\section{DAFTAR PUSTAKA}

Ansari, A,R., Kazi, A.T.G., Jamali, A.M.K., Arain, A.M.B., Wagan, B.M.D., Nusrat Jalbani, C., Afridi, A.H.I \& Abdul Qadir Shah, A.A.Q. 2009. Variation in accumulation of heavy metals in different varieties of sunflower seed oil with the aid of multivariate technique. Food Chem 115: 318-323.

Ariyanto, D.P. 2006. Ikatan antara asam organik tanah dengan logam. Karya Ilmiah SPS Ilmu Tanah. Universitas Gadjah Mada.

Association of Analytical Chemist 2005. Official Methode of Analysis of the Association of Official Analytical Chemist. $17^{\text {th }}$ ed. Washington, D.C.
Balia, R.L., Harlia, E., Denny \& Suryanto. 2007. Keamanan Pangan Hasil Ternak Ditinjau Dari Cemaran Logam Berat. Fakultas Peternakan Universitas Padjadjaran. blogs.unpad.ac.id/roostitabalia/wp-content. (30 Januari 2010).

Charlena. 2004. Pencemaran logam berat timbal $(\mathrm{Pb})$ dan (Cd) pada sayur-sayuran. Falsafah Sain (PSL 702), Program Pascasarjana/S3/Institut Pertanian Bogor. http://www.scribd.com/doc. (30 Januari 2010).

Drazic, G \& Mihailovic, N. 2005. Modification of cadmium toxicity in soybean seedlings by salicylic acid. Plant Sci 168: 511-517.

Gonzales, A.G \& Horrador, M.A. (2007). A pratical guide to analytical methode validation, including measurement uncertainty and accuracy profiles. $\operatorname{TrAC} \mathbf{2 6}$ : 227-238.

Herjuna, S. 2011. Bahan humat sebagai amelioran-abu terbang sebagai amelioran. repository.ipb.ac.id (17 Maret 2012).

Ismail \& Hanudin, E. 2005. Degradasi mineral batuan oleh asam-asam organik. Jurnal Ilmu Tanah dan Lingkungan 5(1): 1-17.

Li, Q., Chai, L., Wang, Q., Yang, Z., Yan, H \& Wang Y. 2010. Fast esterifikasi of spent grain for enhanced heavy metal ions adsorption. Bioresour. Technol 101: 3796-3799.

Mendoza-Cózatl, D.G., Jobe, T.O., Hauser, F \& Schroeder, J.I. 2011. Long-distance transport, vacuolar sequestration, tolerance, and transcriptional responses induced by cadmium and arsenic. Current Opinion in Plant Biology 14(5): 554-562.

Shaha, B.A., Shahb, A.V., Bhandaria, B.N \& Bhatta, R.R. 2008. Synthesis, characterization and chelation ionexchange studies of a resin copolymer derived from 8hydroxyquinoline-formaldehyde-catechol. J Iran. Chem Soc 5(2): 252-261.

Sridhar, S., Kulanthaipandi, P., Arasu, P.T., Thanikachalam, V \& Manikandan, G. 2009. Protonating and chelating efficiencies of some biologically important thiocarbonohydrazides in $60 \%(\mathrm{v} / \mathrm{v})$ ethanol-water system by potentiometric and spectrophotometric methods. World Journal of Chemistry 4(2) : 133-140.

Ullah, S. 2007. Chemically enhanced phytoextraction of lead from contaminated soil. Thesis Doctor. Institute of Soil \& Environment Sciences University of Agriculture, Faisalabad Pakistan.

Yong, Z., Bo-Han, L., Qing-Ru, Z., Min, Z \& Ming, L. 2008. Surfactant linear alkylbenzene sulfonate effect on soil $\mathrm{Cd}$ fractions and $\mathrm{Cd}$ distribution in soybean plant in pot experiment. Pedosphere 18(2): 242-247.

Zander, N.E. 2009. Chelating Polymers and Environmental Remediation. Army Research Laboratory Aberdeen Proving Ground, ARL-CR-0623, MD 21005-5069.

Zheljazkov,V.D., Craker, L.E \& Xing, B. 2006. Effects of $\mathrm{Cd}, \mathrm{Pb}$, and $\mathrm{Cu}$ on growth and essential oil contents in dill, peppermint, and basil. Environ Exp Bot 58: 9-16. 